\title{
Relation of the Upper to Middle Devonian continental deposits in southern Wegener Halvø, central East Greenland
}

\author{
K. Birkenmajer
}

Continental Devonian sediments of southern Wegener Halvø, central East Greenland $\left(71^{\circ}\right.$ $40^{\prime} \mathrm{N}$; fig. 25) have been studied especially by Noe-Nygaard (1934), Säve-Söderbergh (1937) and Bütler (1948). The Devonian stratigraphy was re-examíned in 1968-1970 by geologists from the Scott Polar Research Institute, England (Alexander-Marrack \& Friend, 1976; Friend et al., 1976).

\section{Quensel Bjerg - Store Ravnefjeld area}

In 1971 and 1976 the author mapped the area between Quensel Bjerg and Store Ravnefjeld at a scale of 1:50000. Four lithostratigraphic units have been mapped (fig. 25), the lower three correspond to the Middle Devonian Vimmelskaftet Formation of the Nathorst Fjord Group and the fourth to the Upper Devonian Quensel Bjerg Formation of AlexanderMarrack \& Friend (1976).

(1) This unit (D1 of fig. 25) corresponds to Säve-Söderbergh's (1937) Asterolepis 'series' (division 2) and to the Red Siltstone Member of Alexander-Marrack \& Friend (1976). It consists of predominantly red siltstones and sandstones in bands $0.2-1.5 \mathrm{~m}$ thick with small-scale cross-bedding and ripple bedding, with pale grey, medium-grained sandstone intercalations 2-5 m thick. Only the top part of the unit is exposed in the area investigated, where it exceeds $30 \mathrm{~m}$ in thickness.

(2) This unit (D2 of fig. 25) corresponds to the lower part of Säve-Söderbergh's division 3 and to the Grey Sandstone Member of Alexander-Marrack \& Friend. It consists of grey, micaceous, fine- to medium-grained sandstones in layers 0.3 to $3 \mathrm{~m}$ thick, either with large-scale cross-bedding or with well developed horizontal lamination, sometimes with large-scale slumps. In the lower and upper parts of the unit, there appear red siltstone/claystone intercalations $5 \mathrm{~cm}$ to $2 \mathrm{~m}$ thick. Its-thickness is difficult to establish due to inadequate exposures: it probably exceeds $500 \mathrm{~m}$.

(3) This unit (D3 of fig. 25) corresponds to a higher part of Säve-Söderbergh's Gyroptychius groenlandicus division 3 and to the Red-and-green banded Siltstone Member of Alexander-Marrack \& Friend. It consists of red and green siltstones in bands $5 \mathrm{~cm}$ to $2 \mathrm{~m}$ thick, with intercalations of silty shale $5-25 \mathrm{~cm}$ thick. The siltstones show a wealth of sedimentary structures: small-scale ripple marks (asymmetric, symmetric, interference and linguoid types), often with load-casted ripple bases, ripple-drift, flaser and lenticular (ripple) bedding, convolute bedding, slump balls, desiccation cracks etc. A striking feature is the paucity or absence of current-formed sole markings. Small channels filled with fine-grained sandstone with large-scale cross-bedding and megaripples (sand bars) are rather uncommon and usually appear close to the top of the unit. A very characteristic calcareous-silty band 1.5 $\mathrm{m}$ thick with stromatolites occurs in the uppermost part of the sequence. Burrows and bioturbated layers are very rare. Black or dark-grey (weathered yellow) calcareous- 
$22^{\circ} 45^{\prime}$

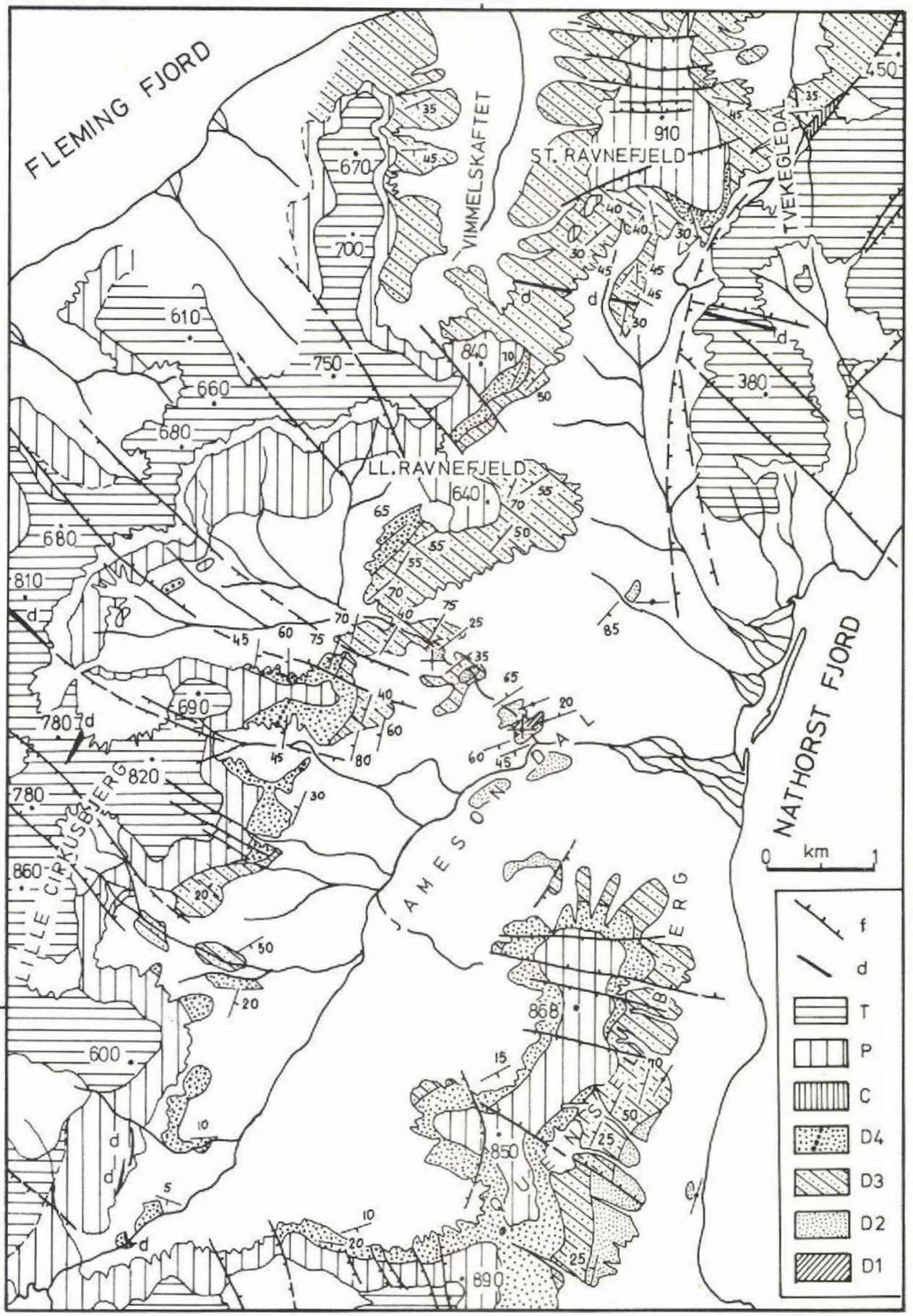

Fig. 25. Geological map of the central-south Wegener Halvø, central East Greenland. f: faults; d: Tertiary dolerite dykes and sills; T: Lower Triassic; P: Permian (mainly Upper Permian); C: Lower Carboniferous; D4; Quensel Bjerg Formation (Upper Devonian); D3-D1: Vimmelskaftet Formation, Middle Devonian. 
bituminous shale intercalations (up to $4 \mathrm{~m}$ thick) with fish fragments occur close to the top of the unit.

The sedimentary character of the unit points to a very shallow, large, flat inland basin with features of both floodplain and inland lake, The thickness of the unit varies between 150 and $850 \mathrm{~m}$.

Units (1) to (3) gradually pass into one another and represent a fining-upward continental cycle deposited at a considerable distance from the source area which was probably to the east.

(4) The fourth unit (= Quensel Bjerg Formation of Alexander-Marrack \& Friend; D4 of fig. 25) is well exposed on the slopes of Quensel Bjerg from where comes a Holoptychius scale indicating its possibly Upper Devonian age (Säve-Söderbergh, 1937). The unit consists predominantly of red and pink, sometimes whitish or grey, fine- to coarse-grained quartzose or arkosic sandstones with large-scale wedge-shaped and planar cross-sets $0.5-1 \mathrm{~m}$ thick, often affected by slumping.

In the basal part of the formation (up to $40 \mathrm{~m}$ above its base) there occur several intercalations 1-3 $\mathrm{m}$ thick of green rippled siltstone and shale of the same type as that observed in the underlying unit (3). Streaks or bands (up to $0.5 \mathrm{~m}$ thick) of well-rounded to subrounded pebbles $0.5-10 \mathrm{~cm}$ in diameter (white and pink quartz, grey and black quartzite, red porphyry, pink and red granite, sometimes also pink fine-crystalline limestone, green basic rocks, purple tuffaceous rocks, etc.), sometimes with an admixture of angular fragments of green silty shale from the underlying unit (3), appear already just above the base of the formation, and become more frequent in its middle part. At Lille Cirkusbjerg conglomerate bands $0.5-1.5 \mathrm{~m}$ thick with rounded pebbles $0.3-20 \mathrm{~cm}$ in diameter (grey quartz, grey and pink quartzite, red porphyry, pink granite) dominate the middle part of the formation.

The upper part of the formation exposed on south-west Quensel Bjerg consists of pink, yellow and deep-red quartzitic or arkosic sandstones and arkoses, medium- to coarsegrained, with large-scale trough- or wedge-shaped cross-sets, in layers $0.5-2 \mathrm{~m}$ thick, alternating with deep-red shale and siltstone. The sandstones are often conglomeratic, with larger fragments of red granite and red feldspar $(0.3-1 \mathrm{~cm}$ in diameter). Red and green shale flakes $(0.5-2 \mathrm{~cm}$ in diameter) may appear at the bottom of numerous channels or between the foresets. Clastic (sandstone) dykes and large desiccation cracks may appear in red shales. There are a few black shale and grey sandstone intercalations 0.1-0.2 m thick. Rippled sandstones are rather uncommon.

The thickness of the Quensel Bjerg Formation is about $600 \mathrm{~m}$. The direction of foresets in cross-bedded units indicates a source of clastics to the east and north-east. There is an angular unconformity between the folded Quensel Bjerg Formation and the overlying Permian.

\section{Relation of the Quensel Bjerg Formation to the Vimmelskaftet Formation}

The base of the Quensel Bjerg Formation is best exposed in the major left tributary of Jameson Elv below Lille Cirkusbjerg (fig. 26). There is no indication of folding and angular unconformity between units (4) and (3) but an erosional unconformity separates them. The unconformity is marked by shallow channels filled with large-scale, cross-bedded, pink, 


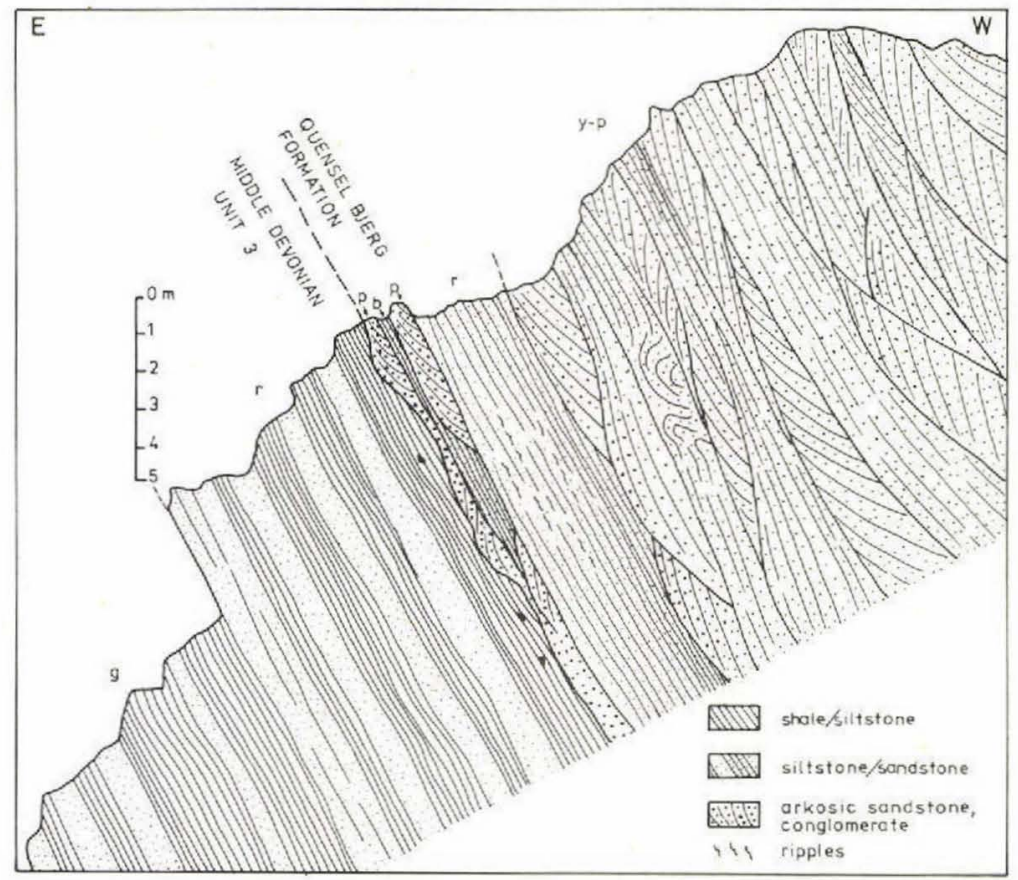

Fig. 26. Contact of the Vimmelskaftet Formation (unit 3) and the Quensel Bjerg Formation (unit 4), Lille Cirkusbjerg, north-east slope, central East Greenland. Colour of the rocks: b: Black; g: green; p: pink; r: red; y: yellow.

arkosic sandstone or conglomerate with lithologies typical for the Quensel Bjerg Formation, which cut through the underlying green and reddish siltstone. Black platy siltstone intercalations of small thickness, with numerous imprints of carbonised plants (up to $20 \mathrm{~cm}$ long and $1-1.5 \mathrm{~cm}$ in diameter), may appear close to the base of the Quensel Bjerg Formation.

The Quensel Bjerg Formation reflects a quick change in sedimentary conditions from flood plain - shallow lake (unit 3) situated at a considerable distance from the source area, to rapidly prograding delta with channels paved with pebble-lag concentrates and filled with cross-bedded sandstones and arkoses cutting through the flood plain. The flood plain conditions typical for unit (3) did not disappear at once, as is evidenced by reappearance of siltstone-shale bands characteristic for unit (3) in the lower $40 \mathrm{~m}$ thick part of the Quensel Bjerg Formation. Some reworking of the older Devonian rocks took place, as is shown by the presence of angular fragments of shale from unit (3) in the pebble-lag concentrates close to the base of unit (4).

The Quensel Bjerg Formation represents a fining-upward continental cycle, with vertical transition from proximal alluvial apron to proximal flood plain, reflecting a major disturbance in the source area. There is no evidence of simultaneous folding, and the observed features of the formation, and the character of its base, may easily be explained by upwarping in the source area. 


\section{Conclusions}

(1) The Quensel Bjerg Formation (Upper Devonian) rests with slight erosional unconformity upon the Vimmelskaftet Formation (Middle Devonian) at Wegener Halvø. This conflicts with the relationship between Upper and Middle Devonian as observed by Bütler (1948, 1959) and Alexander-Marrack \& Friend (1976); there is no evidence of folding of the Vimmelskaftet Formation before the deposition of the Quensel Bjerg Formation. Recurrence of lithologies of unit (3) in the basal part of the unit (4) strongly speaks against any longer break in deposition between these units.

(2) The character of pebbles and abundance of red feldspar locate the source of clastics for the Quensel Bjerg Formation within the Caledonian fold belt and its late Caledonian (Lower - Middle Devonian) effusives and plutons, possibly in the northern and northeastern prolongation of Liverpool Land and Canning Land, now largely part of the East Greenland continental shelf.

(3) Strong tectonic disturbances of the lower part of the Middle Devonian strata versus the higher Middle Devonian and Upper Devonian ones, are partly the result of varying competence of the rocks, but mainly depend on their tectonic position in fold structures formed prior to the Permian. Units (1) and (2) occur in narrow, strongly compressed and faulted disharmonic anticlinal cores, while the majority of unit (3) and unit (4) form the limbs of these anticlines, much less disturbed by compression. In some areas (e.g. at Lille Ravnefjeld) these fold structures are additionally dislocated by post-Mesozoic faults. The author did not confirm the existence of an important pre-Permian fault juxtaposing the Quensel Bjerg Formation to the south against the Nathorst Fjord Group to the north, as distinguished by Alexander-Marrack \& Friend (1976, p. 90; figs 57, 70).

\section{Acknowledgements}

Field assistance from B. Buchardt Larsen and K. Mæhl is acknowledged.

\section{References}

Alexander-Marrack, P. D. \& Friend, P. F. 1976: Devonian sediments of East Greenland. III. The eastern sequence, Vilddal Supergroup and part of the Kap Kolthoff Supergroup. Meddr Grønland 206, 3, $122 \mathrm{pp}$.

Bütler, H. 1948: Notes on the geological map of Canning Land (East Greenland). Meddr Grønland $133,2,97 \mathrm{pp}$.

Bütler, H. 1959: Das Old Red-Gebiet am Moskusoksefjord. Attempt at a correlation of the series of various Devonian areas in Central East Greenland. Meddr Grønland 160, 5, 188 pp.

Friend, P. F., Alexander-Marrack, P. D., Nicholson, J. \& Yeats, A. K. 1976: Devonian sediments of East Greenland. I. Introduction, classification of sequences, petrographic notes. Meddr Grønland 206, $1,56 \mathrm{pp}$.

Noe-Nygaard, A. 1934: Stratigraphical outlines of the area round Fleming Inlet (East Greenland). Meddr Grønland 103, 1, $88 \mathrm{pp}$.

Säve-Söderbergh, G. 1937: On the Palaeozoic stratigraphy of Canning Land, Wegener Peninsula, and Depot Island (East Greenland). Meddr Grønland 96, 5, 41 pp.

Institute of Geology, Polish Academy of Sciences, 